\section{Ethylene Inhibitors Delay Fruit Drop, Maturity, and Increase Fruit Size of 'Arlet' Apples}

\author{
Ross E. Byers, ${ }^{1}$ D.H. Carbaugh, ${ }^{2}$ and L.D. Combs ${ }^{3}$ \\ Virginia Polytechnic Institute and State University, Alson H. Smith, Jr., \\ Agricultural Research and Extension Center, 595 Laurel Grove Road, \\ Winchester, VA 22602
}

Additional index words. Malus domestica, fruit quality

\begin{abstract}
Aminoethoxyvinylglycine (AVG) applied as a spray to 'Arlet' apple trees inhibited fruit drop and increased the pull force necessary to detach the fruit. AVG delayed the loss of fruit firmness, starch degradation, fruit shriveling, and red color development. 1-Methylcyclopropene (1-MCP), applied as a gas or spray to trees in the field, did not affect fruit drop or pull force. The combination of AVG + 1-MCP (spray or gas) provided better control of fruit drop, slowed the loss of fruit firmness, starch degradation, and decrease in pull force than AVG alone. Thirty five days after the optimum harvest date, fruit firmness from trees sprayed with AVG + 1-MCP was maintained at $74.3 \mathrm{~N}$. Fruit of the control was significantly lower at $61.4 \mathrm{~N}$ firmness. The delay in harvest caused untreated control fruit stems to turn brown and die, but stems on AVG treated trees remained green and fruit continued to grow. In the 35 days after the optimum harvest date, treated fruit increased $2.5 \mathrm{~cm}$ in fruit diameter. Chemicals used: Aminoethoxyvinylglycine (AVG), 1Methylcyclopropene (1-MCP), and trisiloxane ethoxylate methyl ether (an organosilicone surfactant, Silwet L-77).
\end{abstract}

Fruit of many apple cultivars may abscise before adequate color or maturity develops. Growers may begin to harvest earlier than the optimum maturity date because adequate labor is often unavailable to harvest large orchards of a single cultivar. Early harvest may lead to poorer fresh and processed fruit quality and poorer fruit storability. Early harvest can also result in lower yields, because fruit that remains on the tree may continue to increase in size (Curtis, 1961; Shallenberger et al., 1961). Chemical sprays that delay preharvest

Received for publication 28 Jan. 2003. Accepted for publication 15 Sept. 2005. Research was partially supported by the Michigan Apple Research Committee, Virginia Apple Research Committee, Virginia Agricultural Council, Valent BioScience Corp., Libertyville, IL, and AgroFresh Inc., Spring House, PA. Appreciation to Maurice Keeler, Harriet Keeler, Jean Engelman, and Tim Stern for data collection, and technical assistance.

${ }^{1}$ Professor of horticulture and scientist-in-charge.

${ }^{2}$ Research specialist.

${ }^{3}$ Research specialist.

fruit drop and maturity for an additional 2 to 4 weeks may increase crop value by increasing yield, fruit size, quality, and price by as much as 20\% (Byers and Eno, 2002). In addition, compressed harvest periods may present several practical problems such as inadequate numbers of picking bins, trucks, and cold storage equipment to handle more fruit in a short period of time.

Chemical control of preharvest fruit drop has been studied for many years (Batjer and Moon, 1945; Batjer and Thompson, 1946; Batjer and Thompson, 1947; Edgerton and Hoffman, 1948; Edgerton, 1947; Gardner et al., 1940; Harley et al., 1946; Mattus and Moore, 1954; Mattus et al., 1956; Smock et al., 1954; Southwick et al., 1953; Thompson 1952). At one time napthaleneacetic acid (NAA), 2,4,5trichlorophenoxy proponic acid (2,4,5-TP), and daminozide (Alar) were registered to delay preharvest apple drop. Daminozide hastened red color development, delayed fruit maturity and fruit drop (Batjer and Williams et al., 1966; Edgerton and Blanpied; 1970; Pollard, 1974).
The registration of daminozide was withdrawn in 1989. When daminozide + NAA or 2,4,5-TP was used to control preharvest drop, a 2- to 4-week extension of the harvest period was possible for many apple cultivars.

The control of fruit drop with 2,4,5-TP was superior to daminozide or NAA, but it caused a hastening of maturity (Mattus and Moore, 1954; Mattus et al., 1956; Smock et al., 1954; Southwick et al., 1953). The optimum harvest period was shortened by 2,4,5-TP even though fruit were held on the tree adequately. Combinations of daminozide and 2,4,5-TP minimized fruit drop, caused negligible fruit ripening (Batjer and Williams, 1966; Edgerton and Blanpied, 1970; Pollard, 1974; Schomer et al., 1971; Smock et al., 1954), increased fruit color, and substantially extended the harvest season. The registration of 2,4,5-TP was cancelled in 1986.

Even though NAA was less effective than 2,4,5-TPor daminozide (Looney and Cochrane, 1981; Southwick et al. 1953; Thompson, 1952), more recent studies indicate that NAA was more effective when applied 3 to 4 weeks before the optimum harvest date followed by a second application 14 to $21 \mathrm{~d}$ afterward for cultivars grown in Virginia (Marini et al., 1993).

Other chemicals that have auxin-like activity will also delay preharvest fruit drop. They include: phenoxys (fenoprop, 2,4-DP), chloroxuron (Looney and Cochrane, 1981; Looney and Hogue, 1987; Marini and Byers, 1988; Marini et al., 1988a, 1989): benzoic acids (dicamba) (Marini and Byers, 1988; Marini et al., 1988b, 1989); and pyridines (triclopyr, lontrel, and fluroxypyr). Among these 2,4-DP and dicamba were superior to NAA because they were longer lasting and had few negative effects on fruit ripening (Marini and Byers, 1988; Marini et al., 1988a, 1988b)

Aminoethoxyvinylglycine(AVG), an ethylene-biosynthesis inhibitor (Shafer etal., 1995 a, 1995b; Yu and Yang, 1979) suppresses ethylene production in apple fruit and other plant tissues (Autio and Bramlage, 1982; Bangerth, 1978). When applied within 1 month of harvest, AVG delays fruit ripening, suppresses preharvest and postharvestflesh softening, reduces watercore, reduces preharvest fruit drop, and increases fruit removal force (Autio and Bramlage, 1982; Bangerth, 1978; Byers, 1997 b, 1997c; Williams, 1980).

1-Methylcyclopropene (1-MCP) is an inhibitor of ethylene action that blocks ethylene

Table 1. Influence of 1-MCP and AVG on 'Arlet' apple fruit quality, shriveled fruit and brown stems at harvest (2000).

\begin{tabular}{|c|c|c|c|c|c|c|c|c|c|c|c|c|}
\hline \multirow[b]{2}{*}{ No. } & \multirow[b]{2}{*}{ Treatment ${ }^{\mathrm{z}}$} & \multirow{2}{*}{$\begin{array}{l}\text { Application } \\
\text { method }\end{array}$} & \multirow{2}{*}{$\begin{array}{c}\text { Shriveled } \\
\text { fruit }(\%) \\
10 \text { Oct. }\end{array}$} & \multirow{2}{*}{$\begin{array}{c}\text { Brown } \\
\text { stem }(\%) \\
10 \text { Oct. }\end{array}$} & \multicolumn{5}{|c|}{$\begin{array}{c}\text { Starch } \\
\text { (1 to } 8 \text { rating) }\end{array}$} & \multicolumn{3}{|c|}{$\begin{array}{l}\text { Pull force } \\
\quad(\mathrm{kg})\end{array}$} \\
\hline & & & & & 8 Aug. & 22 Aug. & 31 Aug. & 19 Sept. & 10 Oct. & 31 Aug. & 19 Sept. & 10 Oct. \\
\hline 1 & Control & & $60 a b c^{y}$ & $67.5 \mathrm{ab}$ & $5.84 \mathrm{a}$ & $6.88 \mathrm{~b}$ & $7.88 \mathrm{a}$ & $8.00 \mathrm{a}$ & $8.00 \mathrm{a}$ & $0.976 \mathrm{c}$ & $0.967 \mathrm{~b}$ & $0.631 \mathrm{~d}$ \\
\hline 2 & 1-MCP + buffer & Gas & $88 \mathrm{a}$ & $74.0 \mathrm{a}$ & $6.36 \mathrm{a}$ & $6.94 \mathrm{~b}$ & $7.96 \mathrm{a}$ & $7.96 \mathrm{ab}$ & $8.00 \mathrm{a}$ & $0.858 \mathrm{c}$ & $1.117 \mathrm{~b}$ & $1.180 \mathrm{bc}$ \\
\hline 3 & 1-MCP + Silwet L-77 & Spray & $68 \mathrm{ab}$ & $56.2 \mathrm{abc}$ & $5.80 \mathrm{a}$ & $7.54 \mathrm{a}$ & $7.88 \mathrm{a}$ & $8.00 \mathrm{a}$ & $8.00 \mathrm{a}$ & $0.949 \mathrm{c}$ & $0.958 \mathrm{~b}$ & $0.917 \mathrm{~cd}$ \\
\hline 4 & AVG (50 ppm) + Silwet L-77 & Spray & $20 \mathrm{~cd}$ & $25.0 \mathrm{~cd}$ & $4.00 \mathrm{~b}$ & $5.44 \mathrm{c}$ & $7.40 \mathrm{~b}$ & $7.96 \mathrm{ab}$ & $8.00 \mathrm{a}$ & $1.398 \mathrm{~b}$ & $1.176 \mathrm{~b}$ & $1.554 \mathrm{a}$ \\
\hline 5 & $\begin{array}{l}\text { AVG }(50 \text { ppm })+\text { Silwet L-77 } \\
1-\mathrm{MCP}+\text { buffer }\end{array}$ & $\begin{array}{l}\text { Spray } \\
\text { Gas }\end{array}$ & $32 \mathrm{bcd}$ & $34.0 \mathrm{bcd}$ & $3.48 \mathrm{~b}$ & $5.22 \mathrm{c}$ & $7.04 \mathrm{~b}$ & $7.92 \mathrm{ab}$ & $8.00 \mathrm{a}$ & $1.557 \mathrm{~b}$ & $1.212 \mathrm{~b}$ & $1.321 \mathrm{ab}$ \\
\hline 6 & AVG $(50 \mathrm{ppm})+1-\mathrm{MCP}+$ Silwet L-77 & $7 \quad$ Spray & $0 \mathrm{~d}$ & $6.0 \mathrm{~d}$ & $4.08 \mathrm{~b}$ & $5.30 \mathrm{c}$ & $7.00 \mathrm{~b}$ & $7.76 \mathrm{~b}$ & $8.00 \mathrm{a}$ & $1.893 \mathrm{a}$ & $1.539 \mathrm{a}$ & $1.217 \mathrm{abc}$ \\
\hline
\end{tabular}

1,2 , and 3 vs. 4,5 , and $6 \quad$ AVG vs. none

${ }^{2}$ Spray treatments were applied with a high-pressure hand-gun sprayer. 1-MCP was applied on 17 July (gas) and 18 July (spray), when fruit firmness was 114.3 N. Chemical rates were $1-\mathrm{MCP}=0.795 \mathrm{mg} / 30 \mathrm{~m}^{3}$ (gas) or $0.795 \mathrm{mg} \cdot \mathrm{L}^{-1}$ (spray); $\mathrm{AVG}=50 \mathrm{mg} \cdot \mathrm{L}^{-1}$; $\mathrm{Silwet} \mathrm{L-77}=0.624 \mathrm{~mL} \cdot \mathrm{L}^{-1} ; \mathrm{buffer}=60 \mathrm{~mL} / 135 \mathrm{~m}{ }^{3}$.

${ }^{y}$ Mean separation within columns by Duncan's new multiple range test; $(P \leq 0.05)$. 


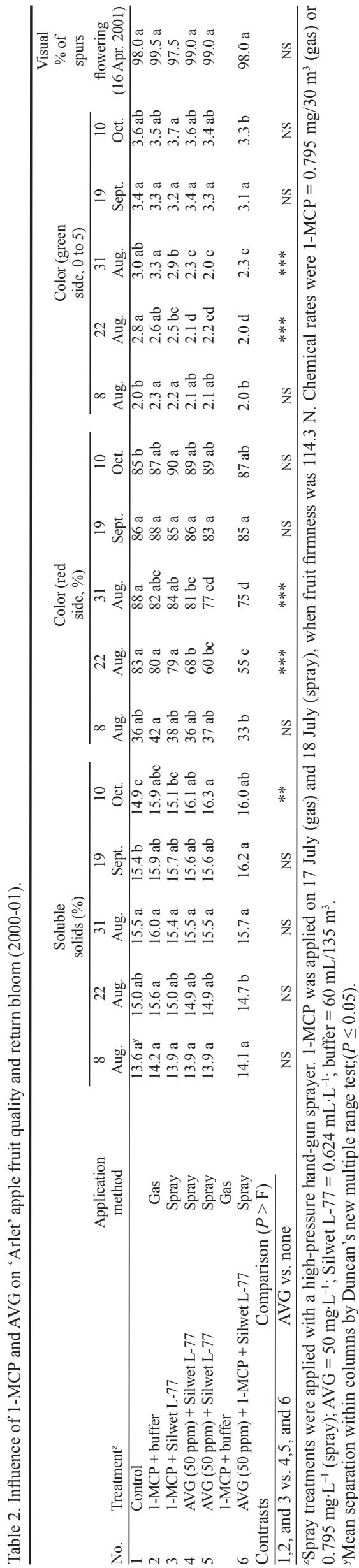

responses in plants (Fan et al., 1999, Serek et al., 1995; Sisler and Serek, 1997). 1-MCP is a gas, which has been formulated as a powder that releases the gas when mixed with a buffered base or water. 1-MCP is currently being used commercially in the cut flower industry and in apple cold storages to prolong the postharvest quality of apples.

In a preliminary experiment in 1999, 'Golden Delicious' trees were gassed in the field with 1-MCP using $135-\mathrm{m}^{3}$ silage bags to contain the gas. At the time of gassing, the control fruit averaged $82.3 \mathrm{~N}$ firmness, but 30 $\mathrm{d}$ after gassing whole trees, fruit measured 81.4 $\mathrm{N}$ flesh firmness when control fruit measured 62.3 N. In comparison, a spray formulation of 1-MCP + superior oil + buffer maintained 'Golden Delicious' fruit firmness at $70.7 \mathrm{~N}$ compared to the control at $62.3 \mathrm{~N}$ (Byers, unpublished). Fruit drop was not controlled by spraying or gassing with 1-MCP.

The objectives of these experiments were to investigate sprays of AVG or 1-MCP (gas or spray) for control of preharvest fruit drop and maintenance of on-tree fruit quality.

\section{Materials and Methods}

In 2000, thirty 5-year-old 'Arlet'/M.7 trees were selected for uniformity and blocked according to row and terrain into five blocks for six treatments (Tables 1, 2, and 3). 1-MCP was applied either as a gas or spray alone or in combination with AVG + Silwet-L-77. Dilute sprays were applied with a low-pressure hand-wand sprayer. Chemicals used (a.i.) were 1-MCP (EthylBloc) at $0.795 \mathrm{mg} / 135 \mathrm{~m}^{3}$ (gas) + proprietary buffer at $60 \mathrm{~mL} / 135 \mathrm{~m}^{3}$, or 1-MCPat $0.795 \mathrm{mg} \cdot \mathrm{L}^{-1}$ (spray);AVG (ReTain) at $50 \mathrm{mg} \cdot \mathrm{L}^{-1}$; Silwet L-77 at $0.624 \mathrm{~mL} \cdot \mathrm{L}^{-1}$ in sprays. Treatments were applied on 18 July at an estimated 4 weeks before the anticipated optimum harvest date (15 Aug.).

1-MCP was applied as a gas to individual trees in the field by enclosing trees in a 10-mil polypropylene silage bag $(3.6 \mathrm{~m}$ in diameter and $6.4 \mathrm{~m}$ in height; however, the trees were only $3.2 \mathrm{~m}$ in height; thus the approximate volume gassed was $30 \mathrm{~m}^{3}$ ). Whole trees were gassed over night from 1800 HR on 17 July to 0800 HR on 18 July, and the bag was taken off early in the morning to prevent sunlight heating. Three grams of 1-MCP dextrose powder ( $0.795 \mathrm{mg}$ a.i.) was placed in $60 \mathrm{~mL}$ of buffer near the trunk of the tree over night. The bag cylinder was tied at the top during gassing and was weighted at the bottom to fit snugly on the ground. Since fruit in a preliminary field test on 'Golden Delicious' trees delayed loss of fruit firmness, the field gassing technique using a 10 mil silage bag was considered adequate for 1-MCP to bind to the ethylene receptor sites. Application of 1-MCP was made within 30 min of aqueous mixing to reduce the potential loss of gas, which occurs within a few hours in water.

A 10-fruit sample was collected near fruit maturity from each tree for quality evaluations (flesh firmness, soluble solids concentration, starch staining, percentage red color, fruit scaring and/or russet, and incidence of water core).
Flesh firmness was measured on two sides of each fruit with an Effegi penetrometer (model FT327; McCormick Fruit Tech, Yakima, Wash.) fitted with an 11.1-mm tip. Soluble solids concentration (SSC) was measured with an Atago hand-held refractometer (model N1; McCormick Fruit Tech), using a composite sample of juice resulting from penetrometer testing of all replicates of each treatment. Each apple fruit was cut in half transversely, and severity of water core was rated on a scale of 0 to $5(0=$ none, $5=$ severe $)$. Flesh starch was evaluated by dipping half of each apple in iodine solution for about $15 \mathrm{~s}$. The degree of staining was rated on a scale of 0 to 8 , where $0=$ staining of the entire cut surface and $8=$ absence of starch (Poapst et al., 1959). Stemend and side russet were rated as $0=$ no russet to $5=$ severe russet. In addition on 10 Oct. each of 10-fruit sampled from each tree was visually observed for obvious fruit shriveling and fruit that had senescing abscission zones and stems and recorded as $0=$ yes or $1=$ no, respectively.

Experimental procedures followed previous work on fruit drop and fruit quality (Byers, 1997 a, 1997b, 1997c; Marini et al., 1988 a, 1998b, 1989). Five to ten limbs per tree (with a minimum of about 50 fruit/tree) were selected and tagged to monitor fruit drop . At 7-d intervals, fruit remaining on these limbs were counted and the percentage of fruit drop was calculated. Fruit samples for testing fruit diameter, firmness, starch, SSC, percent red color, and green color were taken on 8 Aug., 22 Aug., 31 Aug., 19 Sept., and 10 Oct. and pull force on 31 Aug., 19 Sept., and 10 Oct. Data were analyzed by ANOVA and GLM procedures using SAS software (SAS Institute, 1985). Means were compared by Duncan's new multiple range test and single-degreeof-freedom contrasts as appropriate for the experimental design.

\section{Results and Discussion}

1-MCP (EthylBloc) applied as a gas or spray to 'Arlet' apple trees generally did not affect fruit drop (Fig. 1) or pull force (Table 1 , treatments 2,3) required to separate fruit from the spur. AVG inhibited fruit drop (Fig. 1, treatment 4), allowed for continued fruit growth (Fig. 2), delayed loss of fruit firmness (Fig. 3), slowed starch degradation (Table 1), slightly inhibited red color (Table 2), maintained green background color (Table 2), and increased pull force (Table 1) compared to the control. The tank mix spray of 1-MCP (gas or spray) + AVG further inhibited fruit drop (Fig. 1, treatments 5 and 6) and promoted increased SSC, inhibited red color, maintained green background color when compared to AVG alone (Table 2). The combination of AVG + 1-MCP spray applied as a spray provided the best control of fruit drop (Fig. 1, treatment 6), maintenance of fruit firmness (Fig. 3), delaying starch degradation (Table 1), and increased pull force (Table 1) compared to the control. 1-MCP (gas) alone did not inhibit fruit drop (Fig. 1), the loss of firmness (Fig. 3)or starch degradation (Table $1)$, but pull force was greater than the control 


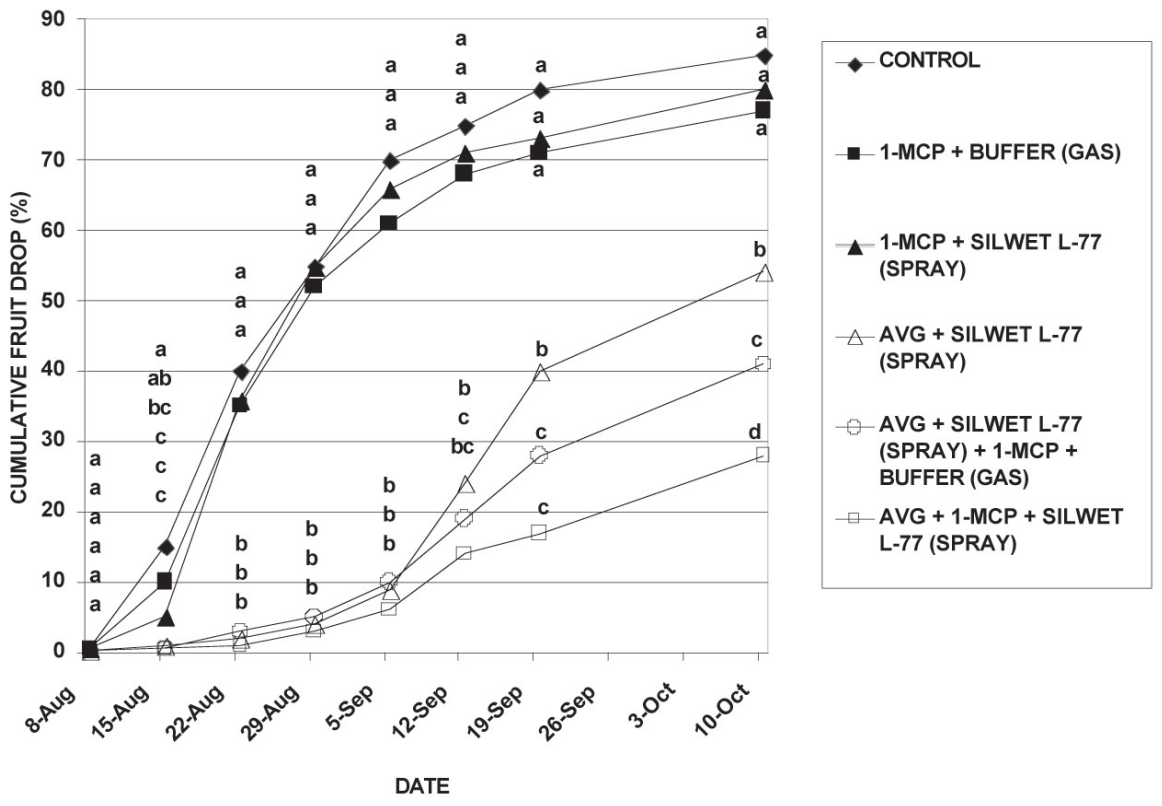

Fig. 1. Influence of 1-MCP and AVG on fruit drop of 'Arlet' apples treated 18 July.

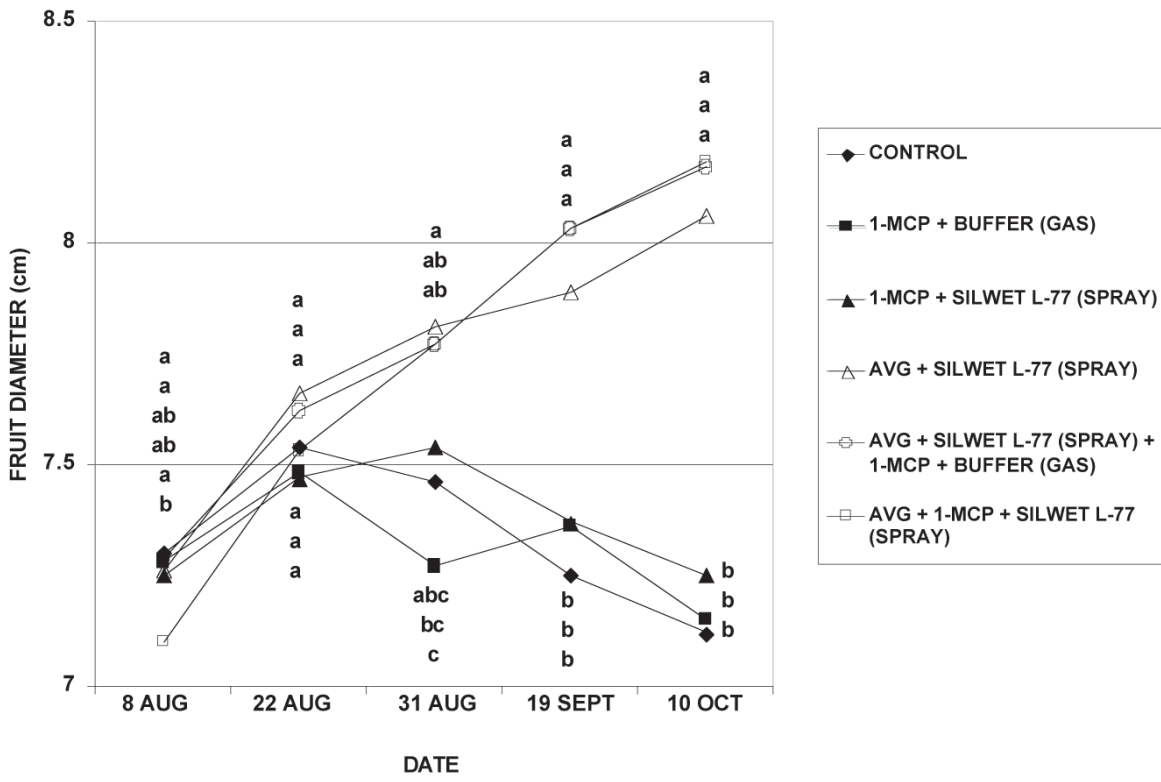

Fig. 2. Influence of 1-MCP and AVG on fruit diameter of 'Arlet' apples treated 18 July when fruit averaged $6.42 \mathrm{~cm}$ in diameter.

on 10 Oct. after most of the fruit had dropped (Table 2).

As the season progressed, fruit sprayed with AVG alone or in combination with 1-MCP (spray or gassing; Fig. 2, treatments 4, 5, and 6) continued to increase in diameter until $10 \mathrm{Oct}$ Fruit from the control and 1-MCP treatments (Fig. 2, treatments 1, 2, and 3) increased in diameter until 22 Aug. Those fruit reached a maximum, and later decreased in diameter(Fig. 2). Of the few, untreated fruit that remained on the tree on 10 Oct., $60 \%$ were shriveled to varying degrees; but none of the AVG or AVG + MCP sprayed fruit (Fig. 4, treatments 4, 5, and 6) were shriveled. The delay in harvest resulted in 1-MCPand/or nontreated fruit stems to turn brown, senesce, and dry while still attached to the tree, but trees sprayed with AVG or AVG + MCP had fruit stems that remained bright green and fruit continued to grow until not inhibit preharvest fruit drop. However, in several experiments, 1-MCP applied either as a gas or spray did not inhibited fruit abscission of apple even though fruit softening was retarded (R. Byers, unpublished data) which indicated that 1-MCP did bind the ethylene receptor sites of the fruit but not the stem. In this 'Arlet' experiment, 1-MCP delayed the loss of firmness only on $22 \mathrm{Aug}$. (Fig. 3). Since $\mathrm{AVG}+1-\mathrm{MCP}$ was superior to AVG alone, the use of both apparently has some additive influences on delaying pedicle senescence, functional organic nutrient transport, and the abscission process.

Anatomical observation of fresh cut, 'Arlet' mature apple abscission zones showed senescent browning in the pith region of the control and 1-MCP (gas and spray treatments) and later in the pedicel cortex region (S. Wolf and R. Byers, unpublished data). AVG $+1-\mathrm{MCP}$ maintained the cortical and vessel regions of the abscission zone, and the entire pedicle of the fruit, in a brighter green condition compared to fruit of the control or 1-MCP treated trees. McCown (1943) indicated that abscission could be initiated independently in the pith or the cortex of the pedicle and that the vessels (xylem, cambium, and phloem) were ruptured as a result of mechanical forces. The weight of the fruit usually caused the final fruit separation by tearing of the cortex and epidermis. The dramatic increase in fruit diameter and maintenance of fruit quality in 'Arlet', was probably the result of maintaining the cortical and phloem tissues in the pedicel and abscission zone from normal senescence and deterioration. Maintenance of these tissues in good conditions has great commercial potential for increasing fruit size, yield, crop value, and greater harvest window.

\section{Literature Cited}

Autio, W.R. and W.J. Bramlage. 1982. Effects of AVG on maturation, ripening, and storage of apples.

Bangerth F. 1978. The effect of a substituted amino acid on ethylene biosyntheses, respiration, ripening and preharvest drop of apple fruit. J. Amer. Soc. Hort. Sci. 103:401-404.

Batjer, L.P. and H.H. Moon. 1945. Effect of naphthaleneacetic acid spray on maturity of apples. Proc. Amer. Soc. Hort. Sci. 46:113-117.

Batjer, L.P. andA.H. Thompson. 1946. Effects of 2,4dichlorophenoxyacetic acid sprays in controlling the harvest drop of several apple varities. Proc. Amer. Soc. Hort. Sci. 47:35-38.

Batjer, L.P. and A.H. Thompson. 1947. Further studies with 2,4-dichlorophenoxyacetic acid sprays in retarding fruit drop of Winesap apples. Proc. Amer. Soc. Hort. Sci. 49:45-48.

Batjer, L.P. and M.W. Williams. 1966. Effects of N-dimethyl amino succinamic acid (Alar) on watercore and harvest drop of apples. Proc. Amer. Soc. Hort. Sci. 88:76-79.

Byers, R.E. 1997a. Peach and nectarine fruit softening following aminoethoxyvinylglucine (AVG) sprays and dips. HortScience 32:86-88.

Byers, R.E. 1997b. Effects of aminoethoxyvinylglycine (AVG) on preharvest fruit drop, maturity, and cracking of sceveral apple cultivars. J. Tree Fruit Prod. 2:77-97.

Byers, R.E. 1997c. Effects of aminoethoxyvinylglycine (AVG) on preharvest fruit drop and 


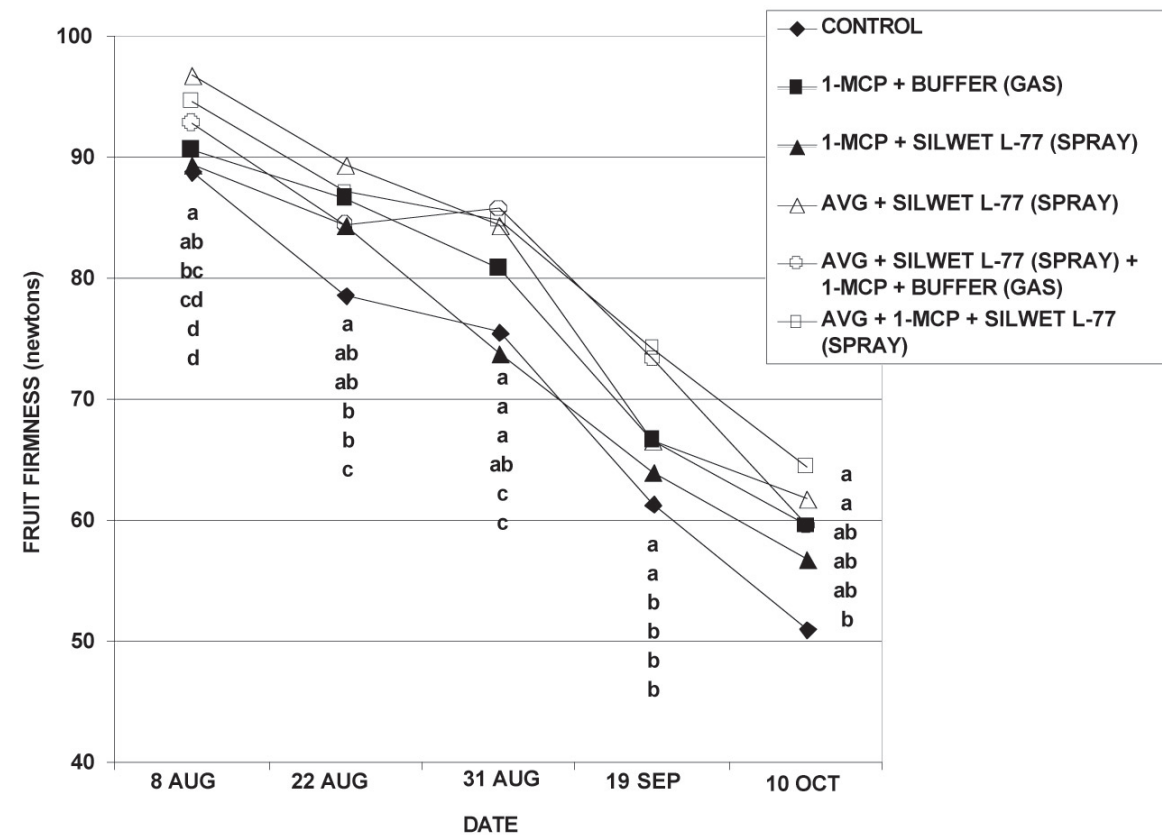

Fig. 3. Influence of 1-MCP and AVG on fruit firmness (114.3 N) of 'Arlet' apples treated 18 July.

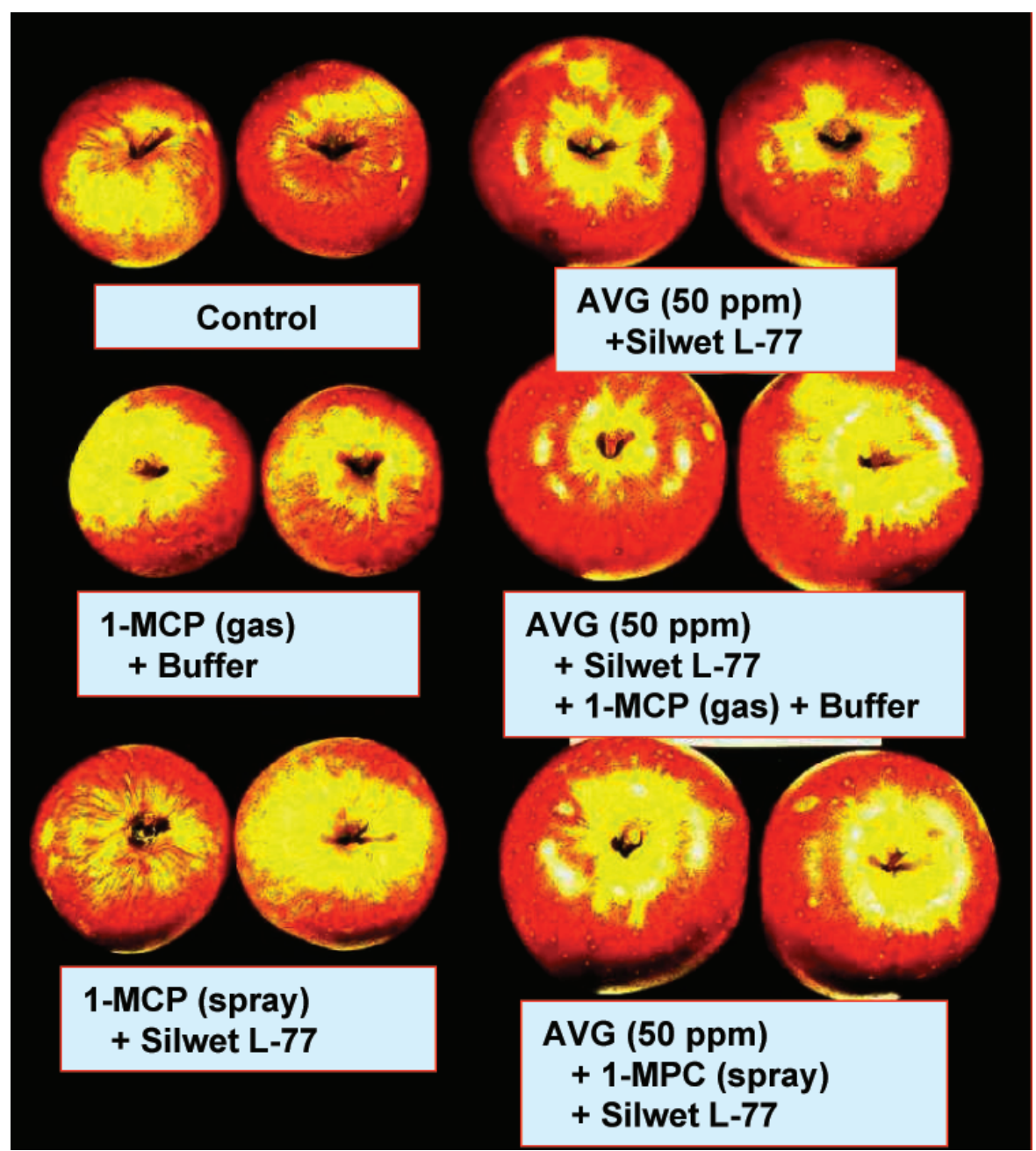

Fig. 4. Influence of AVG (Retain) and/or 1-MCP (EthylBloc) applied as a gas or spray to 'Arlet' apple trees. Fruit were harvested 10 Oct., $50 \mathrm{~d}$ after the typical harvest date of $22 \mathrm{Aug}$. Note that fruit on AVG-sprayed trees continued to enlarge and pedicle abscission zones were healthy and green when picked. In comparison, on 10 Oct., the control, MCP-gas, and MCP-spray fruit were shriveled, abscission zones were in various stages of senescence, and some pedicles were dead and dried while still attached to the tree. maturity of 'Delicious' apples. J. Tree Fruit Prod. 2:53-75.

Byers, R.E. and D.R. Eno. 2002. Harvest date influences fruit size and yield of 'York' and 'Golden Delicous' apple trees. J. Tree Fruit Prod. 3(1):63-79.

Curtis, Jr., O.F. 1961. Upgrading commercial packs of Rhode Island Greening apple slices. II. Crop gain from delayed harvest, p. 72-85. Proc. 1961 Annu.Mtg., N.Y. State Hort. Soc.

Edgerton, L.J. 1947. A method for evaluating the effectiveness of growth substances in delaying apple abscission. Proc. Amer. Soc. Hort. Sci. 49:42-44.

Edgerton, L.J. and G.D. Blanpied. 1970. Interaction of succinic acid 2,2-dimethyl hydrazide, 2-chloroethylphosphonic acid and auxins on maturity, quality and abscission of apples. J. Amer. Soc. Hort. Sci. 95:664-666.

Edgerton, L.J. and M.B. Hoffman. 1948. Tests with 2,4-dichlorophenoxyacetic acid for delaying fruit drop of McIntosh. Proc. Amer. Soc. Hort. Sci. 51:67-70.

Fan X., S.M. Blankensip, and J.P. Pattheis 1999 1-Methylcyclopropene inhibits apple ripening. J. Amer. Soc. Hort. Sci. 124:690-695.

Gardner, F.E., P.C. Marth, and L.P. Batjer. 1940. Spraying with plant growth substances for control of the preharvest drop of apples. Proc. Amer. Soc. Hort. Sci. 37:415-428.

Harley, C.P., H.H. Moon, L.O. Regeimbal, and E.L. Green. 1946.2,4-dichlorophenoxyacetic acid as a spray to reduce harvest fruit drop of apples. Proc. Amer. Soc. Hort. Sci. 47:39-43.

Looney, N.E. and E.J. Hogue. 1987. Chemical control of preharvest fruit drop on 'McIntosh' apple: A comparison of mecoprop chloride, dichlorprop, fenoprop, NAA, and lactidichlor ethyl. HortScience 22:1036 (abstr.)

Looney, N.E. and W.P. Cochrane. 1981. Relative effectiveness of and residue declination values for dichloroprop, fenoprop and napthaleneacetic acid used to control preharvest drop of McIntosh apples. Can. J. Plant Sci. 61:87-91.

Marini, R.P. and R.E. Byers. 1988. Methods for evaluating chemical inhibitors of apple abscission. HortScience 23:849-851.

Marini, R.P., R.E. Byers, D. Sowers, M.E. Marini, and R.W. Young. 1988a. Fruit abscission, fruit quality, and residue levels of dichlorprop used to control preharvest drop of apple. HortScience 23:717-719.

Marini, R.P. and R.E. Byers, D. Sowers, and R.W. Young. 1988b. Fruit abscission and fruit quality of apples following use of dicamba to control preharvest drop. J. Amer. Soc. Hort. Sci. 115:390-394.

Marini, R.P., R.E. Byers, and D.L. Sowers. 1989. Growth regulators and herbicides for delaying apple fruit abscission. HortScience 24:957-959.

Marini, R.P. and R.E. Byers, and D. Sowers. 1993. Repeated applications of NAA control preharvest drop of 'Delicious' apples. J. Hort. Sci. 68:247-253.

Mattus, G.E. and R.C. Moore. 1954. Preharvest growth regulator sprays on apples. I. Drop and maturity 1952 and 1953. Proc. Amer. Soc. Hort. Sci. 64:199-208.

Mattus, G.E., R.C. Moore, and H.A. Rollins, Jr. 1956. Preharvest growth regulator sprays on apples. II. Drop and maturity for 1954 and 1955. Proc. Amer. Soc. Hort. Sci. 67:63-67.

McCown, M. 1943 Anatomical and chemical aspects of abscission of fruit of apple. Bot. Gaz. $105: 212-220$

Pollard, J.E. 1974. Effects of SADH, ethephon and 2,4,5-T on color and storage quality of 'McIntosh ' apples. J. Amer. Soc. Hort. Sci. 99:341-343. 
Poapst, P.A., G.M. Ward, and W.R. Phillips. 1959. Maturation of McIntosh apples in relation to starch loss and abscission. Can. J. Plant Sci. 39:257-263.

SAS Institute. 1985. SAS user's guide and SAS statistical procedures. SAS Institute, Cary, N.C.

Schupp, J.R. and D.C. Ferree. 1988. Effects of root pruning at four levels of severity on growth and yield of 'Melrose'/M.26 apple trees. J. Amer. Soc. Hort. Sci. 113:194-198

Schomer, H., M.W. Williams, and H.D. Billingsley. 1971. Effect of combinations of growth regulators on maturity and quality of 'Tydeman's Red' apples. HortScience 6:453-455.

Serek, M., E.C. Sisler, and M.S. Reid. 1995. Effects of 1-MCP on the vase life and ethylene response of cut flowers. Plant Growth Regulat. 16:93-97.

Shafer, W.E., G. Clarke, J. Hansen, D. Woolard, B N. Defisetty, and R. Fritts. 1995a. Practical applications of aminoethoxyvinylglycine, $\mathrm{p}$. 11-15. Proc. 22nd Annu. Mtg. Plant Growth Regulat. Soc. Amer.

Shafer, W.E., R. Fritts, and B.N. Defisetty. 1995b. A Commercial formulation of aminoethoxyvinylglycine (AVG) for use on apples. Proc. 91stAnnu. Mtg. Wash. State Hort. Assn. (in press).

Shallenberger, R.S., R.L. Labelle, and J.C. Moyer. 1961. Upgrading commercial packs of RhodeIsland greening apple slices-Maturity and processing studies, p. 72-85. Proc. Annu. N.Y. State Hort. Soc.

Sisler, E.C. and M. Serek. 1997 Inhibitors of ethylene responses in plants at the receptor level: Recent developments. Physiol. Plantarium 100:577-582.

Smock, R.M., L.J. Edgerton, and M.B. Hoffman. 1954. Some effects of stop drop auxins and respiratory inhibitors on the maturity of apples. Proc. Amer. Soc. Hort. Sci. 63:211-219.
Southwick, F.W., I.E. Demoranville, and J.F. Anderson. 1953. The influence of some growth regulating substances on preharvest drop, color, and maturity of apples. Proc. Amer. Soc. Hort. Sci. 61:155-162.

Thompson, A.H. 1952. Further experiments with 2,4,5-trichlorophenoxypropionic acid sprays for control of the preharvest drop of apples. Proc. Amer. Soc. Hort. Sci. 60:175-183.

Walsh, C.S. 1977. The relationship between endogeneous ethylene and abscission of mature apple fruit. J. Amer. Soc. Hort. Sci. 103615-619.

Williams, M.W. 1980. Retention of fruit firmness and increase in vegetative growth and fruit set of apples with aminoethoxyvinylglycine. HortScience 15:76-77.

Yu, Y.B. and S.F. Yang. 1979. Auxin-induced ethylene production and its inhibitors by aminoethoxyvinylglycine and cobalt ion. Plant Physiol. 64:1074-1077. 